Horseman, Dr. and Mrs. Stuart Houston (compilers), Ronald McDonald, Preston McDonald, Bob Pearce, Wayne Pearce, Elwood Sharpe, Cliff Shaw, Jeff Smith, Donald Swaby. (Yorkton Natural History Society).

Ed. note: The following report came in too late to be totalled with the above reports.

FORT SAN, Dec. 22, $28 \mathrm{mi}$. by car in $10 \mathrm{mi}$. area, $3 \frac{1 / 4}{\mathrm{hrs}} 9$ species, 208 individuals. Golden Eagle, 1;
Downy Woodpecker, 3; Black-bille Magpie, 7; Black-capped Chickade 12; Northern Shrike (?); House Spa row, 70; Evening Grosbeak, 3; Rec poll, 110; Snow Bunting, 1. (Ad C o m m o n Merganser, Ruffe Grouse, Hairy Woodpecker, Blue Ja White-breasted Nuthatch, Bohemic Waxwing, Pine Grosbeak.) - Jad Lowe, Errol Cochrane, John Lenno E. M. Callin.

\title{
Goshawk Trapping in Alberta
}

\section{By A. F. Oeming, President, Edmonton Zoological Society}

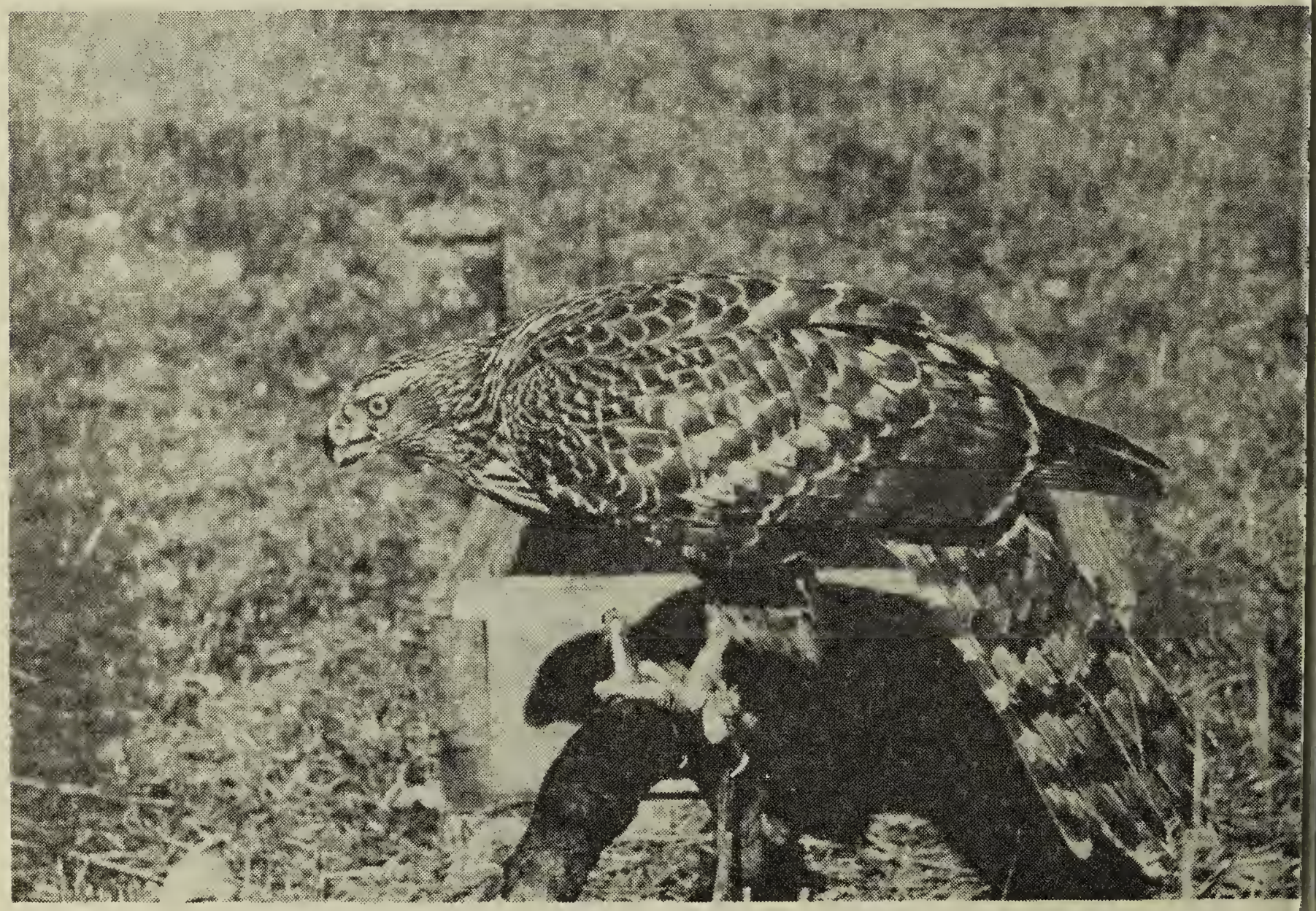

Photo by Heinz Meng

Immature female Goshawk on bow perch.

My interest in the live trapping of the Goshawk, Astur atricapillus, was prompted by an active interest in the art of falconry and a desire to band a number of these not too common raptors. From 1949 to 1951 I took a small number of birds, using such laborious trapping methods as the hand bow-net with tethered pigeons. Not until the year 1952, and after a considerable number of trapping techniques had been experimented with, did I manage to devise a fool-proof method that would allow for a worthwhile number of Goshawks to be captured each season. This was through the use of the
Swedish Goshawk trap (Figure of a pattern similar to those used the gamekeepers of Sweden. T trap has the advantage of not quiring constant supervision. Ot traps used, such as the autom: bow-net and various German mal invariably cramped the captive $b$ so that in its struggles in the $t$ much of its plumage was dama A bird with any part of its plum damaged is of no value to a falcor The Swedish trap, when well net allows the newly captured Goshar to move from end to end freely with no feather damage. The Sw ish trap is simple to build and of 
ate and the Goshawks enter it with a minimum of delay. We always used live pigeons as lures. The pigeons are so enclosed that they are never in danger of being injured by the Goshawks.

The location of such a trap is the all important feature of Goshawk trapping. It should be placed on a high knoll or hill, preferably along a wooded river valley. Goshawks follow such valleys and seldom miss spotting the pigeons in the trap. The hill itself must be ringed with woods for the Goshawk is fond of making its attack with a short fast flight from a treed area. Traps set in wide open fields were never successful.

Goshawks begin their fall and winter movements towards the end of August. In the early fall there is often a sudden run of Goshawks that will last for the better part of a week, and this is often the case again in mid-winter. No trapping is carried on in the breeding and nesting season. Trapping is usually begun in September and is carried on until the end of March.

For a number of years I have searched some of the heaviest wooded regions in Northern Alberta, looking, among other things, for nesting Goshawks. I have, to this date, found only six nests of this species.
The rather remarkable run of Goshawks in the trapping season might well indicate that these birds have moved in from areas of some distance. The Goshawk does nest to the limit of the treeline, north.

The majority of the Goshawks trapped were sent out to members of the Falconry Club of America and trained for hunting. Others were banded.

The table showing the dates, ages and weights of birds captured is rather interesting. Of the 54 Goshawks listed in the table the ratio of males to females is $1: 1$. The ratio of immature birds to mature is $2: 1$. It was not difficult to distinguish the mature birds from the immature for all the immature birds still had the brown plumage of the juveniles, and the mature birds had handsome blue and slate gray colouring. Eye colour in the mature birds is aiways a brilliant orange-red while the immature birds show the yellow iris. One can distinguish male and female Goshawks on the basis of size alone. A large female Goshawk appears almost twice the size of an average male bird. The largest bird that I captured was a female weighing 2 pounds and 14 ounces. The lightest bird captured was an immature male weighing 1 pound, 8 ounces.

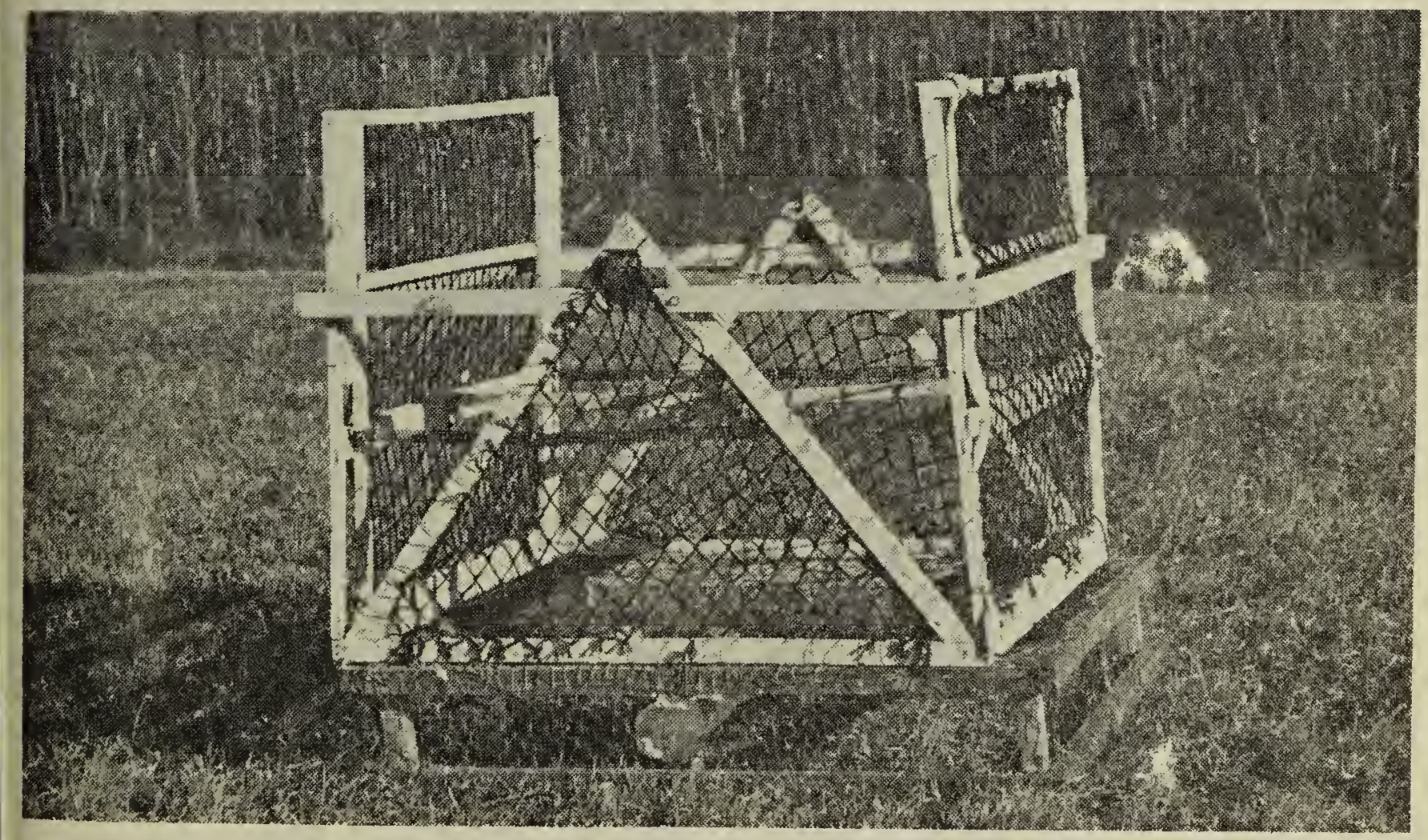

Pheto by A. F. Oeming.

The Swedish style Goshawk trap. Goshawks enter the trap from the top. They land on a centre tick which is hinged in the middle and collapses immediately with the weight of the hawk. pringed sides close the trap. This trap would provide a humane method of removing predators rom game farms, for Great Horned Owls as well as Goshawks are readily taken in such a trap. 
Table 1.

Weights of Goshawks Captured 1952-1957

\section{Date}

Feb. 6, 52 Jan. 30,53

Feb. 5,53

Feb. 10,53

Feb. 12, 53

Feb. 14, 53

Mar. 4, 53

Mar. 4, 53

July 5,53

Sep. 20, 53

Sep. 27, 53

Sep. 30,53

Oct. 27,53

Dec. 10,53

Dec. 14,53

Dec. 23,53

Oct. 20, 54

Nov. 19,54

Nov. 20,54

Nov. 21, 54

Dec. 1, 54

Dec. 1,54

Dec. 6,54

Dec. 6,54

Dec. 7,54

Dec. 10,54

Feb. 22, 55

Feb. 24, 55

Mar. 2, 55

Mar. 14, 55

Dec. 4, 55

Dec. 4,55

Dec. 8, 55

Apr. 2,56

Sep. 2,56

Oct. 15,56

Oct. 25,56

Oct. 26, 56

Nov. 1,56

Nov. 2,56

Nov. 4,56

Nov. 8,56

Nov. 8,56
Sex Age Wt. Loc.

M I 1-12 Fl.

$M \quad$ I $2-0$ Fl.

M I 2-0 Fl.

F I $2-51 / 2$ Fl.

M A $1-15$ Fl.

F I $2-7$

M I $1-13$

F I $2-51 / 2$

M I $1-12$

M I $1-11$

F I $2-4$

F A 2-3

M A $1-9$

F A $2-12$

M A 1-14

M A $1-15$

M I $1-8$

F A $2-10$

F A 2-11

M I $1-15$

M A 2-1

F A $2-10$

M I $2-3$

M I $1-13$

F I $2-5$

F I $2-11$

M I 1-14

F I 2-11

M I 2-0

M A 2-1

M I 2-3

M I 1-13

F I $2-9$

M I 2-0

F I $2-9$

F I $2-9$

F A $2-9$

M I $1-14$

F I $2-93 / 4$

F A $2-61 / 2$

M I $1-11$

F A 2-14

F A 2-11
Nov. 14,56

Nov. 18, 56

Nov. 22, 56

Nov. 25, 56

Dec. 12,56

Dec. 15,56

Dec. 22, 56

Jan. 11, 57

Jan. 12, 57

Feb. 14, 57

Mar. 28, 57

$\begin{array}{ccll}\text { F } & \text { A } & 2-10 & \text { Ed. } \\ \text { F } & \text { I } & 2-8 & \text { Ed } \\ \text { F } & \text { I } & 2-10 & \text { Ed } \\ \text { F } & \text { A } & 2-8 & \text { Ed } \\ \text { M } & \text { I } & 1-14 & \text { Ed } \\ \text { M } & \text { I } & 2-1 & \text { Ed } \\ \text { M } & \text { I } & 2-3 & \text { Ed } \\ \text { M } & \text { I } & 1-12 & \text { Ed } \\ \text { F } & \text { I } & 2-12 & \text { Ed } \\ \text { F } & \text { I } & 2-9 & \text { Ed } \\ \text { F } & \text { A } & 2-63 / 4 & \text { Ed }\end{array}$

Note: Goshawks are classified a: male or female, adult or immature Weights are given in pounds anc ounces. The locations recorded above are Fl. - Flatbush, Ed. - Edmontor and Ba.-Barhead.

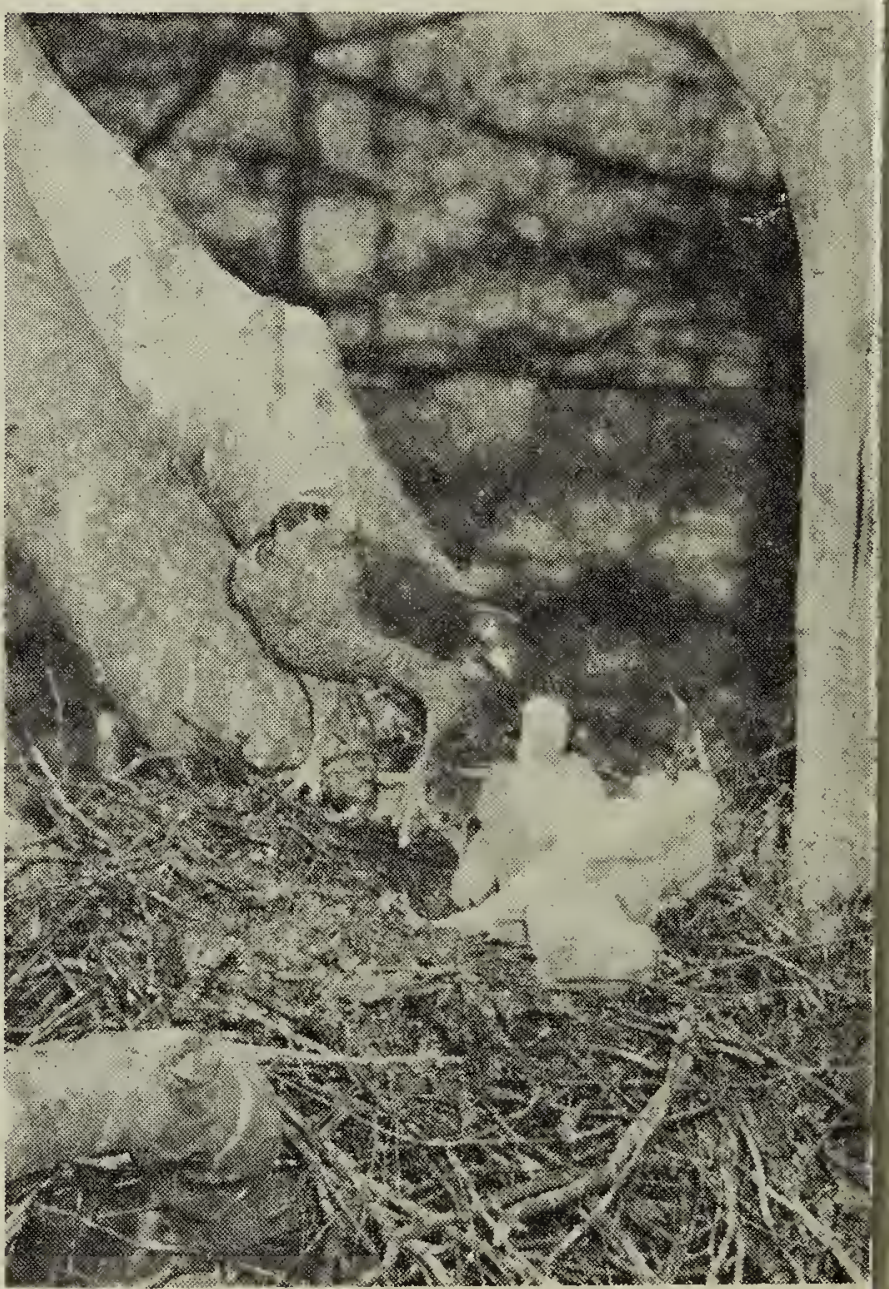

Photo by Heinz Meng

Female Goshawk at nest with three youn Note mature plumage.

Table 2.

Summary: Numbers and Weights of Goshawks Captured

\begin{tabular}{l|c|c|c|c|c|c}
\hline & $\begin{array}{c}\text { Total } \\
\text { Males }\end{array}$ & $\begin{array}{c}\text { Total } \\
\text { Females }\end{array}$ & $\begin{array}{c}\text { Mature } \\
\text { Males }\end{array}$ & $\begin{array}{c}\text { Mature } \\
\text { Females }\end{array}$ & $\begin{array}{c}\text { Imma ture } \\
\text { Males }\end{array}$ & $\begin{array}{c}\text { Immature } \\
\text { Females }\end{array}$ \\
\hline $\begin{array}{l}\text { Numbers of } \\
\text { Goshawks }\end{array}$ & 27 & 27 & 6 & 12 & 21 & 15 \\
\hline Average Weights & $1-14.3$ & $2-8.7$ & $1-14.5$ & $2-9.3$ & $1-14.3$ & $2-8.3$ \\
\hline
\end{tabular}

